\title{
Annelerin tamamlayıcı beslenme hakkındaki tutum ve yaklaşımları
}

\author{
Approaches and attitudes of mothers about complementary feeding
}

\author{
Gizem Şenyazar, Şule Gökçe, Feyza Koç
}

\section{Öz}

Amaç: Beslenme özellikle ilk bir yaş için sağlıklı büyüme ve gelişmede en önemli unsurdur. Çalışmada annelerin bebeklerini ne kadar süre sadece anne sütüyle beslediklerini, tamamlayıcı beslenmeye ne zaman başladıklarını ve tamamlayıcı beslenmeye geçişte kararlarını etkileyen faktörleri saptamak amaçlanmıştır.

Gereç ve yöntem: Çalışmaya, 12-36 ay arasında Ege Üniversitesi Tıp Fakültesi'nde Sosyal Pediatri, Genel Pediatri ve diğer polikliniklerde takibe alınmış toplam 300 olgu dahil edildi. Yazılı onam formu alındıktan sonra anneler ile tek tek ve yüz yüze görüşülerek hazırlanmış anket formu dolduruldu.

Bulgular: Çalışmaya 174 (\%58) erkek, 126 (\%42) kız olmak üzere toplam 300 çocuk dahil edildi. Olguların yaş ortalaması 22,5 $\pm 7,8$ ay idi. Çalışmada yer alan $293(\% 97,7)$ bebek doğumdan sonraki ilk 24 saat içinde anne sütü almıştı, fakat tek başına anne sütü ile başlama oranı \%78,3 idi $(n=235)$. Sadece anne sütü ile beslenme süresi ortalama $4 \pm 2,5$ aydı. İlk 6 ayda sadece anne sütü ile beslenme oranı ise $\% 47,7$ idi. Annelerin ilk 24 saat içinde anne sütü verme eğilimi yüksek iken, sadece anne sütü verme oranı yeterli düzeyde değildi. Anne sütüne ek olarak doğumda formül mamaların da yüksek düzeyde verildiği gözlendi. Toplam anne sütü alma süresi $14 \pm 7,8$ ay, tamamlayıcı beslenmeye başlama yaş ortalaması ise 5,6 $\pm 1,2$ aydı ve $\% 29,3$ 'üne 6 . aydan önce tamamlayıcı beslenme başlanmıştı. Annelere 6 . aydan önce niçin tamamlayıcı beslenmeye başladıkları sorulduğunda, en yaygın cevap "Tattırmak amaçlı" $(\% 37,5)$ idi.

Sonuç: Çalışmamız annelerin anne sütü konusunda istekli olduklarını fakat tatlandırma isteği, bebeğin emmeyi reddettiği düşüncesi, anne sütünün yetmediği düşüncesi, bebeğin sürekli ağlaması gibi çeşitli nedenler ile farklı beslenme şekillerini denediklerini göstermiştir. Çalışmamızda her ne kadar oran düşük gözükse de tamamlayıcı beslenmeye hala erken başlanmaktadır. Anne eğitiminin doğumdan önce ve sonrasında da devam edilmesi, beslenme konusunda annelerin bilgi düzeylerinin arttırılması gerekmektedir.

Anahtar kelimeler: Anne sütü, bebek, tamamlayıcı beslenme, beslenme.

Şenyazar G, Gökçe Ş, Koç F. Annelerin tamamlayıcı beslenme hakkındaki tutum ve yaklaşımları. Pam Tıp Derg 2021;14:836-845.

\begin{abstract}
Purpose: Nutrition is the most important factor in healthy growth and development, particularly for the first age. The aim of our study was to determine how long mothers fed their babies only with breast milk, when they started complementary food and the factors that affect their decision to start complementary food.

Materials and methods: A total of 300 cases between 12-36 months that were monitored in social pediatrics, general pediatrics, and other outpatient clinics at Ege University Faculty of Medicine were included in the study. After receiving the written consent form, the questionnaire prepared by meeting the mothers individually and face-to-face was filled out.

Results: A total of 300 children, 174 boys (58\%) and 126 girls (42\%) were included in the study. The mean age of the children was $22.5 \pm 7.8$ months. Two hundred ninety-three of the cases $(97.7 \%)$ have been fed with breast milk within the first 24 hours after delivery; however, only breast milk percent was $78.3 \%(n=235)$. The mean time of only breast milk feeding was $4 \pm 2.5$ months. The rate of nutrition only with breast milk in the first 6 months was $47.7 \%$. Although the mothers have a high tendency of giving breast milk in the first 24 hours, the rate of giving only breast milk is not at sufficient level. It is observed that the formula was also given at a high level at birth in addition to breast milk. The total period of taking breast milk was $14 \pm 7.8$ months and the mean duration of starting the complementary feeding was $5.6 \pm 1.2$ months and $29.3 \%$ of the cases have been started the complementary feeding before the 6th month. When the mothers were asked why they started complementary feeding before the 6th month, the most common answer was "for tasting" (37.5\%).

Conclusions: Our study showed that mothers are willing to breastfeed, but they try different forms of nutrition for various reasons, such as to sweeten, the idea that the baby refuses the breastfeeding, the idea that breast milk is not enough, and the baby's constant crying. Although the rate seems low in our study, complementary

Gizem Şenyazar, Uzm. Dr. Ege Üniversitesi Tıp Fakültesi, Çocuk Sağlığı ve Hastalıkları Anabilim Dalı, İzmir, Türkiye, e-posta: gizemsenyazar@ gmail.com (https://orcid.org/0000-0003-1313-9426)

Şule Gökçe, Öğr. Gör. Ege Üniversitesi Tıp Fakültesi, Çocuk Sağlığı ve Hastalıkları Anabilim Dalı, İzmir, Türkiye, e-posta: sule.gokce@yahoo. com (https://orcid.org/0000-0003-3392-4990) (Corresponding Author)

Feyza Koç, Doç Dr. Ege Üniversitesi Tıp Fakültesi, Çocuk Sağlığı ve Hastalıkları Anabilim Dalı, Sosyal Pediatri Bilim Dalı, İzmir, Türkiye,
\end{abstract} e-posta: feyzaumaykoc@yahoo.com (https://orcid.org/0000-0002-5891-8506) 
nutrition is still started early. It is necessary to continue maternal education before and after delivery and to increase the knowledge level of mothers about nutrition.

Key words: Breast milk, infant, complementary feeding, nutrition.

Senyazar G, Gokce S, Koc F. Approaches and attitudes of mothers about complementary feeding. Pam Med J 2021;14:836-845.

\section{Giriş}

Beslenme; çocukluk çağında sağlıklı büyüme ve gelişme için gerekli en temel faktördür. Bu konuda yapılan hatalı ve bilinçsiz uygulamalara bağlı gelişen olumsuz etkiler; sadece çocukluk çağında değil, yaşamın bütün dönemlerinde gözlenebilmektedir. Dünya Sağlık Örgütü (DSÖ) ve Amerikan Pediatri Akademisi (AAP) bebeklerin ilk 6 ay sadece anne sütü ile beslenmelerini, altıncı ayda mutlaka tamamlayıcı beslenmeye geçilmesini ve emzirmenin 2 yıl sürdürülmesini tavsiye etmektedir [1, 2].

Anne sütü ile beslenme; bebek mortalite ve morbidite oranlarını azaltır, bebeğin sağlıklı büyüme ve gelişmesini sağlar. Anne sütü bebeğin gereksinim duyduğu besin içeriği ve enfeksiyonlara karşı koruyucu özellikleri nedeniyle yaşamın ilk anından itibaren verilmesi gereken tek fizyolojik besindir. Yeterli süre ve miktarda verilen anne sütü ile zamanında uygun tamamlayıcı beslenme başlanması ve çeşitlendirilerek devam edilmesi temel çocuk gelişimi açısından son derece önemlidir. Dünya Sağlık Örgütü verilerine göre çocuk ölümlerinin $\% 7$ 'sinin birinci, \%46'sının ise ikinci nedeni yetersiz ve dengesiz beslenmedir [2]. Türkiye Nüfus ve Sağlık Araştırmaları (TNSA) verilerine göre bebek formül mamaları ve diğer sıvılara erken başlama ülkemizde de oldukça yaygın bir uygulamadır. Türkiye Nüfus ve Sağlık Araştırmaları 2008 verilerinde bebeklerin $\% 8$ 'i 6. aydan önce tamamlayıcı beslenmeye geçerken bu oran 2013 TNSA verilerinde artarak \%12 olarak tespit edilmiştir. Yine TNSA 2018 verilerine göre de bebeklerin \%23'ü anne sütü dışı süt almakta ve \%12'si anne sütüne ilave tamamlayıcı beslenme almaktadır. Diğer taraftan bebeklere verilen tamamlayıcı gıdaların ayına uygun verilmediği de saptanmıştır. Bu durum tamamlayıcı gıdaya geçiş sürecinin hala önemli bir sorun olduğunu göstermektedir [3].

$\mathrm{Bu}$ çalışma ile annelerin tamamlayıcı beslenmehakkındakibilgidüzeylerininölçülmesi, ne kadar sadece anne sütü ile beslediklerini, ne zaman tamamlayıcı beslenmeye geçtiklerini, tamamlayıcı beslenmeye geçiş kararını vermelerinde etkili olan faktörlerin belirlenmesi amaçlanmıştır.

\section{Gereç ve yöntem}

Ege Üniversitesi Tıp Fakültesi Çocuk Sağlığı ve Hastalıkları Anabilim Dalı, Sağlıklı Çocuk İzlem Polikliniği, Genel Pediatri Polikliniği, diğer yan dal polikliniklerine başvuran ve/veya serviste yatarak izlenen $12-36$ ay arasındaki çocuklar çalışmaya alındı. Kesitsel anket çalışması olarak planlanan bu çalışma Ege Üniversitesi Tıp Fakültesi Girişimsel Olmayan Klinik Araştırmalar Etik Kurulu tarafından onaylandı. Çalışmaya alınan çocukların ailelerine anket öncesi bilgi verildi ve yazılı bilgilendirilmiş onam formu alındı.

"Ekonomik düzey" Türk-iş tarafından Ağustos 2017 de yayınlanan sınıflamaya göre düzenlenmiştir. Bu sınıflamaya göre aylık gelir 1500 TL altı "Kötü", 1500-4900 TL arası "Orta" ve 4900 TL ve üzeri "İyi" olarak nitelendirilmiştir [4].

Çalışmaya $12-36$ ay arasında, kronik hastalık, prematüre doğum ( $\leq 37$ hafta), hastanede uzun süre yatış (>1ay) ve besin alerjisi öyküsü olmayan çocuklar alındı. Çalışma için toplam 374 aile ile görüşme yapıldı; 36 tanesi çalışma koşullarını sağlamadığı için, 15 aile çalışmayı kabul etmediği için, 23 aile de anne bilgileri yeterli hatırlanmadığı için çalışma dışı bırakıldı ve toplam 300 anket ile çalışma tamamlandı.

\section{İstatistiksel analiz}

Çalışmaya alınan olguların ve ailelerinin sosyodemografik özelliklere ilişkin verileri tanımlayıcı tablolara dönüştürüldü. Araştırmadan elde edilen veriler SPSS (Statistics 22) programında analiz edildi. Öncelikle tüm değişkenler için tanımlayıcı istatistikler yapıldı. Kategorik değişkenler arasındaki fark için $\mathrm{X}_{2}$ kare testi, sayısal değişkenler arasındaki ilişki için Spearman's korelasyon analizi uygulandı. 
İstatiksel olarak verilerin karşılaştırılmasında iki bağımsız grup varsa Mann Whitney $U$ testi ve ikiden fazla grup varsa Kruskal Wallis testi uygulandı. $P<0,05$ istatistiksel olarak anlamlı kabul edildi.

\section{Bulgular}

Olguların \%58'i erkek, \%42'si kIz idi. Çalışmaya alınan olguların \%44,7'si $(n=134)$ ailenin ilk çocuğuydu. Olguların \%38,3'ü $(n=115)$ ailenin ikinci çocuğu, \%12,7'si ( $n=38)$ ailenin üçüncü çocuğu, \%4,3'ü $(n=13)$ ise 3 . gebelikten sonra doğmuş çocuklardı. Çalışmaya dahil edilen olguların/ailelerinin sosyo-ekonomik verileri ve olguların beslenme şekilleri Tablo 1 'de özetlenmiştir.

Çalışmamıza dahil edilen ailelere anne sütü alımı ile ilgili sorula yöneltildiğinde; Hiç anne sütü almayan \%2,3 $(n=7)$ olgununun anne sütü alamama nedeni olarak anneler "sütüm gelmedi" cevabını vermişti. İlk 6 ayda sadece anne sütü ile beslenme oranı \%47,7 ( $n=143)$ idi. Olguların \%4'ü $(n=14)$ 7. aya kadar, \%2'si $(n=6)$ 11. aya kadar, \%0,3'ü $(n=1) 12$ aya kadar sadece anne sütü ile beslenmeye devam etmişti. Bebeklerin 293'ü $(\% 97,6)$ doğumdan sonra ilk 24 saat içinde anne sütü almıştı, ancak sadece anne sütü alanlara bakıldığında bu oran $\% 78,3$ $(n=235)$ 'tü. Doğumdan sonra ilk 24 saatte anne sütü alanların \%19,7'si ( $n=58)$ anne sütü ile birlikte formül mama ile beslenmişti. Olguların $\% 75^{\prime i}(n=225)$ ilk 2 ayda sadece anne sütü ile beslenirken yaşla birlikte bu oran azalmaktaydı.

Illk 6 ay sadece anne sütü ile beslenen grup ile diğer beslenme şekillerini alan gruplar arasında bu duruma etki eden faktörler irdelendiğinde ailenin kaçıncı çocuğu olması ile beslenme arasında ilişki görülmedi $(p>0,05)$. Anne ve babaların eğitim düzeyi ile ilk 6 ay sadece anne sütü verme arasındaki ilişkiye bakıldığında, annelerin okuryazar olmayanlarının \%33,3'ü $(n=6)$, ortaokul mezunu olanların $\% 36,4$ 'ü $(n=24)$, üniversite mezunu olanların $\% 57,3$ 'ü $(n=47)$ bebeklerini ilk 6 ay sadece anne sütü ile beslemişti. Anne ve baba eğitim düzeyi ile beslenme şekli arasında anlamlı bir ilişki saptanmadı $(p>0,05)$ (Tablo 2$)$.

Tablo 3'te toplam anne sütü alma süresine etki eden faktörler irdelenmiştir. Anne eğitim düzeyine göre toplam anne sütü alma süresi arasındaki ilişkiye bakıldığında, okuryazar olmayanların toplam anne sütü alma süresi ortalama $15,1 \pm 8,3$ ay, ortaokul mezunu olanların $14,4 \pm 7,2$ ay, üniversite mezunu olanların $14,6 \pm 7,3$ ay saptandı. Annenin eğitim düzeyi ile toplam anne sütü alma süresi arasında ilişki saptanmadı $(p>0,05)$. Ekonomik düzeyini "iyi" olarak değerlendiren ailelerin toplam anne sütü alma süresi ortalama $14,5 \pm 8$ ay, "orta" olarak değerlendirenlerin $13,9 \pm 7,7$ ay, kötü olarak değerlendirenlerin $15 \pm 8,2$ ay saptandı. Ailelerin ekonomik düzeyi ile toplam anne sütü alma süresi arasında istatistiksel bir ilişki bulunamadı $(p>0,05)$.

Çalışma grubunun tamamlayıcı beslenmeye başlama yaşı ortalama $5,6 \pm 1,2$ ay idi. Olguların 88 'ine $(\% 29,3) 6$. aydan önce ve bunların 9'una (\%3) 4. aydan önce tamamlayıcı beslenme verilmişti. Dokuz (\%3) olguya 8 . ayda, $1(\% 0,3)$ olguya 9 . ayda, $2(\% 0,7)$ olguya ise 12 . ayda tamamlayıcı beslenme başlanmıştı. Anne eğitim düzeyine göre tamamlayıcı beslenme başlama zamanı arasındaki ilişkiye bakıldığında, okuryazar olmayanların ek gıdaya başlama zamanı ortalama $6 \pm 1,9$ ay, ortaokul mezunu olanların $5,3 \pm 1$ ay, üniversite mezunu olanların $5,7 \pm 0,8$ ay idi fakat istatistiksel anlamlı bir ilişki saptanmadı $(p>0,05)$. Ev hanımı olan annelerin ek gıdaya başlama zamanı ortalama $5,6 \pm 1,2$ ay, çalışan annelerin $5,7 \pm 1,1$ ay idi. Annenin çalışma durumu ile ek gıdaya başlama zamanı arasında da anlamlı bir ilişki yoktu $(p>0,05)$. Benzer şekilde ailelerin ekonomik düzeyi ile ek gıdaya başlama zamanı arasında anlamlı farklıık saptanmadı $(p>0,05)$. Annelerin tamamlayıcı beslenmeye geçişte hangi besinler ile başlandığı değerlendirildiğinde; $\% 99,6$ 'sı yoğurt ile $\% 86,3$ 'ü peynir ile $\% 57,3$ 'ü ise muhallebi ile başladıklarını belirtmişlerdir. Olguların tamamlayıcı beslenmeye geçiş özellikleri, diğer tamamlayıcı beslenme ürünleri ve ürünlerin başlanma zamanları Tablo 4'te belirtilmiştir.

Tamamlayıcı beslenmeye başlama zamanına etki eden faktör olarak çocuğun cinsiyeti, kaçıncı çocuk olması, annenin doğum yaptığındaki yaşı, anne-baba eğitim, annenin çalışma durumu, ailenin ekonomik durumu değerlendirildi (Tablo 5). Anne eğitim düzeyine göre tamamlayıcı beslenmeye başlama zamanı arasındaki ilişkiye bakıldığında, okuryazar olmayanların tamamlayıcı beslenmeye başlama zamanı ortalama $6 \pm 1,9$ ay, ortaokul mezunu olanların $5,3 \pm 1$ ay, üniversite mezunu olanların $5,7 \pm 0,8$ ay saptandı. Annenin eğitim düzeyi 
Tablo 1. Olguların/ailelerin temel demografik özellikleri ve olguların beslenme şekilleri

\begin{tabular}{|c|c|c|c|}
\hline Hasta özellikleri & & $\mathrm{n}$ & $\%$ \\
\hline Yaş (ortalama \pm SS), ay & $22,5 \pm 7,8$ & & \\
\hline \multirow[t]{2}{*}{ Cinsiyet } & Erkek & 174 & 58 \\
\hline & $\mathrm{K} ı \mathrm{Z}$ & 126 & 42 \\
\hline \multirow[t]{2}{*}{ Doğum şekli } & NSVY & 113 & 37,7 \\
\hline & $\mathrm{C} / \mathrm{S}$ & 187 & 62,3 \\
\hline \multirow[t]{3}{*}{ Doğum ağırlığı, gr } & $<2500$ & 25 & 8,3 \\
\hline & $2500-3500$ & 194 & 64,7 \\
\hline & $>3500$ & 81 & 27 \\
\hline \multirow[t]{4}{*}{ Ailenin kaçıncı çocuğu } & Illk & 134 & 44,7 \\
\hline & 2. & 115 & 38,3 \\
\hline & 3. & 38 & 12,7 \\
\hline & $>3$ & 13 & 4,3 \\
\hline \multicolumn{4}{|l|}{ Beslenme şekilleri } \\
\hline & Sadece anne sütü & 143 & 47,7 \\
\hline & Anne sütü ve formül mama & 66 & 22 \\
\hline & Anne sütü, formül mama, Tamamlayıcı beslenme & 49 & 16,3 \\
\hline & Anne sütü ve Tamamlayıcı beslenme & 32 & 10,7 \\
\hline & Formül mama ve Tamamlayıcı beslenme & 4 & 1,3 \\
\hline & Sadece formül mama & 3 & 1 \\
\hline & Anne sütü, formül mama, ek gıda, inek sütü & 3 & 1 \\
\hline Aile özellikleri & & n & $\%$ \\
\hline Anne yaşı (ortalama $\pm S S$ ), yaş & $30,9 \pm 5,6$ & & \\
\hline Annenin doğum yaşı (ortalama $\pm S S$ ), yaş & $29 \pm 5,6$ & & \\
\hline \multirow[t]{5}{*}{ Anne eğitim (mezuniyet) } & Okuryazar değil & 18 & 6 \\
\hline & İlkokul & 62 & 20,7 \\
\hline & Ortaokul & 66 & 22 \\
\hline & Lise & 72 & 24 \\
\hline & Üniversite & 82 & 27,3 \\
\hline \multirow[t]{5}{*}{ Baba eğitim (mezuniyet) } & Okuryazar değil & 6 & 2 \\
\hline & İlkokul & 62 & 20,7 \\
\hline & Ortaokul & 56 & 18,6 \\
\hline & Lise & 93 & 31 \\
\hline & Üniversite & 83 & 27,7 \\
\hline \multirow[t]{2}{*}{ Annenin iş durumu } & Ev hanımı & 227 & 75,7 \\
\hline & Çalışıyor & 73 & 24,3 \\
\hline \multirow[t]{2}{*}{ Babanın iş durumu } & İşsiz & 14 & 4,7 \\
\hline & Çalışıyor & 286 & 95,3 \\
\hline \multirow[t]{3}{*}{ Ailenin ekonomik düzeyi } & İyi & 63 & 21 \\
\hline & Orta & 203 & 67,7 \\
\hline & Kötü & 34 & 11,3 \\
\hline
\end{tabular}

SS: Standard sapma 
Tablo 2. İlk 6 ay sadece anne sütü alan grup ile diğer beslenme şekillerini alan grubun karşılaştııılması

\begin{tabular}{|c|c|c|c|}
\hline & \multicolumn{2}{|c|}{ İlk 6 ay beslenme } & \multirow[t]{2}{*}{$p$} \\
\hline & $\begin{array}{l}\text { Sadece anne sütü ile } \\
\text { beslenen grup } \\
(\mathrm{n}=143) \\
\mathrm{n}(\%)\end{array}$ & $\begin{array}{l}\text { Diğer beslenme } \\
\text { şekillerini alan grup } \\
(\mathrm{n}=157) \\
\mathrm{n}(\%)\end{array}$ & \\
\hline \multicolumn{4}{|l|}{ Cinsiyet } \\
\hline Erkek & $77(44,3)$ & $97(55,7)$ & 0,164 \\
\hline Kız & $66(52,4)$ & $60(47,6)$ & \\
\hline \multicolumn{4}{|c|}{ Doğum ağırlığı, gr } \\
\hline$<2500$ & $9(36)$ & $16(64)$ & 0,231 \\
\hline $2500-3500$ & $90(46,4)$ & $104(53,6)$ & \\
\hline$>3500$ & $44(54,3)$ & $37(45,7)$ & \\
\hline \multicolumn{4}{|l|}{ Kaçıncı çocuk } \\
\hline İlk & $65(48,5)$ & $69(51,5)$ & 0,950 \\
\hline 2. & $53(46,1)$ & $62(53,9)$ & \\
\hline 3. & $18(47,4)$ & $20(52,6)$ & \\
\hline$>3$ & $7(53,8)$ & $6(46,2)$ & \\
\hline \multicolumn{4}{|c|}{ Anne eğitim (mezuniyet) } \\
\hline Okuryazar değil & $6(33,3)$ & $12(66,7)$ & 0,081 \\
\hline İlkokul & $32(51,6)$ & $30(48,4)$ & \\
\hline Ortaokul & $24(36,4)$ & $42(63,6)$ & \\
\hline Lise & $34(47,2)$ & $38(52,8)$ & \\
\hline Üniversite & $47(57,3)$ & $35(42,7)$ & \\
\hline \multicolumn{4}{|c|}{ Baba eğitim (mezuniyet) } \\
\hline Okuryazar değil & $2(33,3)$ & $4(66,7)$ & 0,380 \\
\hline İlkokul & $29(46,8)$ & $33(53,2)$ & \\
\hline Ortaokul & $25(44,6)$ & $31(55,4)$ & \\
\hline Lise & $40(43)$ & $53(57)$ & \\
\hline Üniversite & $47(56,6)$ & $36(43,4)$ & \\
\hline \multicolumn{4}{|c|}{ Annenin iş durumu } \\
\hline Ev hanımı & $104(45,8)$ & $123(54,2)$ & 0,257 \\
\hline Çalışıyor & $39(53,4)$ & $34(46,6)$ & \\
\hline \multicolumn{4}{|c|}{ Ailenin ekonomik düzeyi } \\
\hline İyi & $32(50,8)$ & $31(49,2)$ & 0,790 \\
\hline Orta & $94(46,3)$ & $109(53,7)$ & \\
\hline Kötü & $17(50)$ & $17(50)$ & \\
\hline
\end{tabular}


Tablo 3. Toplam anne sütü alma sürelerini etkileyebilecek faktörlerin irdelenmesi

\begin{tabular}{|c|c|c|}
\hline & Toplam anne sütü alma süresi (ortalama \pm SS), ay & $p$ \\
\hline Cinsiyet & & 0,289 \\
\hline Erkek & $13,7 \pm 7,9$ & \\
\hline Kız & $14,7 \pm 7,7$ & \\
\hline Kaçıncı çocuk & & 0,393 \\
\hline İlk çocuk & $13,3 \pm 7,5$ & \\
\hline 2. çocuk & $14,3 \pm 8,2$ & \\
\hline 3. çocuk & $16 \pm 7,7$ & \\
\hline$>3$ & $14,5 \pm 1,5$ & \\
\hline Anne eğitim (mezuniyet) & & 0,720 \\
\hline Okuryazar değil & $15,1 \pm 8,3$ & \\
\hline İlkokul & $13,9 \pm 8,3$ & \\
\hline Ortaokul & $14,4 \pm 7,2$ & \\
\hline Lise & $13,3 \pm 8,2$ & \\
\hline Üniversite & $14,6 \pm 7,3$ & \\
\hline Baba eğitim (mezuniyet) & & 0,512 \\
\hline Okuryazar değil & $17,5 \pm 12,6$ & \\
\hline İlkokul mezunu & $13,2 \pm 8$ & \\
\hline Ortaokul mezunu & $14,8 \pm 8,3$ & \\
\hline Lise mezunu & $13,6 \pm 7,5$ & \\
\hline Üniversite mezunu & $14,5 \pm 7,1$ & \\
\hline Annenin iş durumu & & 0,515 \\
\hline Ev hanımı & $14,3 \pm 7,9$ & \\
\hline Çalışıyor & $13,6 \pm 7,5$ & \\
\hline Ailenin ekonomik düzeyi & & 0,648 \\
\hline İyi & $14,5 \pm 8$ & \\
\hline Orta & $13,9 \pm 7,7$ & \\
\hline Kötü & $15 \pm 8,2$ & \\
\hline
\end{tabular}

SS: Standart sapma 
Tablo 4. Olguların tamamlayıcı beslenmeye geçiş özellikleri, tamamlayıcı beslenme ögeleri ve başlangıç zamanları

\begin{tabular}{|c|c|}
\hline Tamamlayıcı beslenmeye geçiş özellikleri & n (\%) \\
\hline Tamamlayıcı beslenmeye geçiş, (ortalama \pm SS), ay & $5,6 \pm 1,2$ \\
\hline $0-4$ & $9(3)$ \\
\hline $4-6$ & $79(26,3)$ \\
\hline$>6$ & $212(70,7)$ \\
\hline \multicolumn{2}{|l|}{ Tamamlayıcı beslenmeye erken geçiş nedenleri } \\
\hline Tattırmak amaçlı & $33(37,5)$ \\
\hline Bebeğin emmeyi reddetmesi & $24(27,2)$ \\
\hline Sütümün yetersiz olduğunu düşüyorum & $20(22,7)$ \\
\hline Sürekli ağlıyordu & $8(9)$ \\
\hline Bebeğin yetersiz kilo alımı, doktor tavsiyesi & $2(2,3)$ \\
\hline Bebeğin sağlık sorunu & $1(1,13)$ \\
\hline Tamamlayıcı beslenme ürünleri & Başlangıç süre (Ortalama \pm SS), ay \\
\hline Yoğurt (n=299) & $6 \pm 1,4$ \\
\hline Muhallebi $(n=172)$ & $6,8 \pm 2$ \\
\hline Yumurta sarısı (n=287) & $7,1 \pm 2,2$ \\
\hline Peynir (n=259) & $7,3 \pm 2,3$ \\
\hline Et $(n=290)$ & $9,5 \pm 3,1$ \\
\hline Yumurta beyazı ( $n=275)$ & $9,6 \pm 2,7$ \\
\hline Tavuk (n=276) & $10 \pm 3,3$ \\
\hline Balık (n=247) & $10,3 \pm 3,5$ \\
\hline Köfte (n=278) & $10,8 \pm 3,1$ \\
\hline Keçi sütü (n=24) & $11,3 \pm 4$ \\
\hline İnek sütü (n=239) & $12,2 \pm 4,3$ \\
\hline
\end{tabular}

SS: Standart sapma 
Tablo 5. Tamamlayıcı beslenmeye geçişi etkileyebilecek faktörler

\begin{tabular}{|c|c|c|}
\hline & $\begin{array}{l}\text { Tamamlayıcı beslenme başlama zamanı } \\
\text { (ortalama } \pm \text { SS), ay }\end{array}$ & $p$ \\
\hline Cinsiyet & & 0,419 \\
\hline Erkek & $5,6 \pm 1,3$ & \\
\hline $\mathrm{K} ı \mathrm{z}$ & $5,7 \pm 0,9$ & \\
\hline Kaçıncı çocuk & & 0,483 \\
\hline İlk & $5,6 \pm 1,2$ & \\
\hline 2. & $5,5 \pm 1$ & \\
\hline 3. & $5,7 \pm 1$ & \\
\hline$>3$ & $6,1 \pm 2,1$ & \\
\hline Anne eğitim (mezuniyet) & & 0,173 \\
\hline Okuryazar değil & $6 \pm 1,9$ & \\
\hline İlkokul & $5,6 \pm 1,1$ & \\
\hline Ortaokul & $5,3 \pm 1$ & \\
\hline Lise & $5,7 \pm 1,4$ & \\
\hline Üniversite & $5,7 \pm 0,8$ & \\
\hline Baba eğitim (mezuniyet) & & 0,063 \\
\hline Okuryazar değil & $6,2 \pm 2,9$ & \\
\hline İlkokul & $5,6 \pm 1,2$ & \\
\hline Ortaokul & $5,6 \pm 1,1$ & \\
\hline Lise & $5,4 \pm 1,3$ & \\
\hline Üniversite & $5,8 \pm 1,2$ & \\
\hline Annenin iş durumu & & 0,680 \\
\hline Ev hanımı & $5,6 \pm 1,2$ & \\
\hline Çalışıyor & $5,7 \pm 1,1$ & \\
\hline Ailenin ekonomik düzeyi & & 0,763 \\
\hline İyi & $5,6 \pm 1$ & \\
\hline Orta & $6,7 \pm 1,1$ & \\
\hline Kötü & $5,6 \pm 1,5$ & \\
\hline
\end{tabular}

SS: Standart sapma

ile tamamlayıcı beslenmeye başlama zamanı arasında ilişki saptanmadı $(p>0,05)$.

\section{Tartışma}

Sağlıklı beslenme-özellikle bebeklik döneminde- büyüme ve gelişme için çok önemli rol oynamaktadır. Anne sütü ile beslenme sağlıkı beslenmenin ilk ve en önemli adımıdır. İlk 6 ay sadece anne sütü ile beslenme önerilirken, 6 . aydan itibaren bebeğin besin gereksinimlerini anne sütü tek başına karşılayamaz ve tamamlayıcı besinlerin başlanması gerekir. Ancak 2 yaşına kadar emzirmeye de devam edilmelidir [2]. Dünya genelinde, düşük emzirme ve erken tamamlayıcı beslenmeye geçiş uygulamaları ne yazık ki yaygındır. Dünyada ilk 6 ay sadece anne sütü alma oranı
\%38 olarak bildirilmektedir. Dünya Emzirme Eğilimleri Girişimi (World Breastfeeding Trends İnitiative)'nin verilerine göre ise ilk 6 ayda sadece anne sütü alma oranı $\% 41$ olarak açıklanmıştır [5]. Norveç'te yapılan çalışmada anne sütü alanların oranı 1. ayda $\% 90,4$. ayda $\% 44$ ve 6 . ayda \%7 saptanmıştır [6]. Ülkemizde ise TNSA 2018 verilerine göre 6 . ayda sadece anne sütü alma oranı $\% 41$ 'dir ve sadece anne sütü alan çocukların ortanca emzirilme süresi 1,8 aydır [3]. Çalışmamızda doğumdan sonra ilk 24 saatte anne sütü alma oranı oldukça yüksek $(\% 97,7)$ bulunmasına rağmen sadece anne sütü alma oranına bakıldığında bu oran $\% 78,3$ saptandı ve ilk 24 saatte anne sütü alanların \%19,7'sinin anne sütüne ek olarak formül mama da aldığı saptandı. Yaşla birlikte 
sadece anne sütü alma oranı da azalmaktaydı. Olguların, 2. ayda \%75'i, 6. ayda \%47,7'si sadece anne sütü almaktaydı. Sadece anne sütü ile beslenmedeki başarısızlığın en önemli nedeni, doğumdan hemen sonra anne sütünün verilmesinin gecikmesi, emzirme sorunu yaşayan annelerde bu sorunun çözümünde de hemen formül mamaya geçilmesidir [7]. Türkiye Nüfus ve Sağlık Araştırmaları 2018 verilerinde ilk bir gün içinde emzirilme oranı $\% 71,2$. ayda $\% 58,6$. ayda \%30,1 olarak bulunmuştur [3]. Yine İzmir'de Ünsal ve ark.'nın [8] toplam 5003 anneyi içeren çalışmalarında, annelerin \%93,7'sinin doğumda bebeklerini emzirmeye başladıkları, \%6,3 bebeğin ise hiç anne sütü almadığı belirtilmiştir. Yine aynı çalışmada bebeklerini emziren annelerin tek başına anne sütü verme durumlarına bakıldığında; doğumda \%97 bebek sadece anne sütü alırken 2 aylık olduklarında bu oran $\% 81,5 ; 4$. ayda oran $\% 46,2 ; 6$. ayda ise \%8,7'ye düşmüştür. Ülkemizde emzirmeye başlama oranları yüksek olmasına rağmen ilk 6 ay sadece anne sütü verme ve emzirmeye devam etme konusunda eksikler mevcuttur.

Dünya Sağlık Örgütü, UNICEF, ESPGHAN tamamlayıcı besinlere 6. ayda başlanılmasını önermektedir [9-11]. Buna karşın ülkemiz dahil, gelişmiş ve gelişmekte olan birçok ülkede yapılan çalışmalarda, önerilerin aksine tamamlayıcı besinlere erken başlandığı belirlenmiştir. İngiltere'de 4. aydan önce \%51 oranında tamamlayıcı beslenme başlandığı, Almanya'da \%16'sının 3. ayda başladığı bildirilmiştir [12, 13]. Türkiye Nüfus ve Sağlık Araştırmaları- 2018 verilerinde ise 6. aydan önce tamamlayıcı beslenme başlama oranı \%14,6 olarak bulunmuştur [3]. Köksal ve ark.'nın [14] yaptığı bir çalışmada 12-23 aylık çocukların \%45,9'una 6. aydan önce tamamlayıcı beslenme başlanmış, Ünalan ve ark.'nın [15] çalışmasında ise bebeklerin \%58'ine 6 . aydan önce, \%33'üne 0-3 ayda, \%25'ine ise 3-6 ayda tamamlayıcı beslenme başlanmıştı. Tamamlayıcı beslenmeye erken başlama için en sık neden "sütüm yetmiyordu" ve "doymuyordu, ağlıyordu" şeklinde cevaplardı. Nepal'de yapılan bir çalışmada da anneler tamamlayıcı beslenme erken başlama nedeni olarak "sütümün yetersiz olduğunu düşünüyordum" olarak belirtmişti [16].

Çalışmamızda çocuğun cinsiyeti, kaçıncı çocuk olması ile tamamlayıcı beslenmeye erken başlama arasında ilişki saptanmamıştır. Beş Avrupa ülkesinde yapılmış çalışmada genç annelerin tamamlayıcı besinlere erken dönemde başladığı saptanmıştır [17]. Anne ve baba eğitim düzeyinin tamamlayıcı besinlere uygun zamanda başlamayı etkileyen bir faktör olduğu çalışmalarla belirtilmiştir, anne eğitim düzeyi arttıkça tamamlayıcı beslenmeye zamanında başlandığı, baba eğitimi arttıkça tamamlayıcı beslenme başlama zamanı ile ilgili bilginin arttığı saptanmıştır [17-19]. Bizim çalışmamızda tamamlayıcı beslenmeye başlama zamanının anne yaşından etkilenmediği belirlenmiştir.

Çalışmamızın en büyük kısıtııı̆ı kesitsel olması ve az sayıda katılım ile gerçekleşmiş olmasıdır. Sonuçlar Türkiye genelini yansıtamadığı gibi anneler tarafından verilen bilgilerin yetersiz ve yanlış olma olasılığı da mevcuttur. Annelere tamamlayıcı beslenme konusundaki davranışları ile ilgili sorular yöneltilmiş olsa da çevresel ailevi faktörler ülkemiz için göz ardı edilmemelidir. Tamamlayıcı beslenmeye geçiş sırasında aile büyüklerinin hala çok önemli bir faktör olabileceğini düşünmekteyiz.

Sonuç olarak; annelerin ilk 24 saat içinde anne sütü verme eğilimleri yüksekken, yalnızca anne sütü verme oranı düşüktür ve yüksek oranda doğumda anne sütüne ek olarak formül mama da verilmektedir. Her ne kadar oran düşük gözükse de tamamlayıcı beslenmeye erken başlanmaktadır ve uygun zamana göre uygun tamamlayıcı beslenme konusunda eksikler mevcuttur. İlk 6 ay sadece anne sütü alma, toplam anne sütü alma ve tamamlayıcı beslenme başlama zamanının bebek ve aile sosyodemografik özelliklerinin arasında ilişki saptanmamıştır. Ayrıca sonuçlarımız annelerin anne sütü konusunda istekli olduklarını fakat yanlış inanış ve uygulamalar ile farklı beslenme şekillerini denediklerini göstermiştir. Altıncı ayda bebeklerin gereksinimlerini anne sütünün karşılayamadığı tamamlayıcı beslenme ihtiyacının olduğu bu dönem sağlıklı büyüme ve gelişmenin sağlanmasında büyük önem arz etmektedir. Anne eğitiminin doğumdan önce ve sonrasında da devam edilmesi, annelerin bu dönemde desteklenmesi ve emzirmeye teşvik edilmesi, ilk 6 ay sadece anne sütü konusunda ısrar edilmesi ve tamamlayıcı beslenme konusunda annelerin bilgi düzeylerinin arttırılması gerekmektedir.

Çıkar ilişkisi: Yazarlar çıkar ilişkisi olmadığını beyan eder. 


\section{Kaynaklar}

1. Pérez Lizaur AB. Complementary feeding. Gac Med Mex 2011;147:39-45.PMID: 22352127

2. PAHO. Guiding principles for complementary feeding of the breastfed child. Washington: Pan American Health Organization, World Health Organization, 2003. Available at: http://www.who.int/child_adolescent_ health/documents/a85622/en/index.htm. Accessed December, 2003

3. Hacettepe Üniversitesi Nüfus Etütleri Enstitüsü. Türkiye Nüfus ve Sağlık Araştırması 2018. Erişim adresi: http://www.hips.hacettepe.edu.tr/tnsa2018/ rapor/TNSA2018_ana_Rapor.pdf. Erişim tarihi Kasım, 2019

4. Türk-İş Açlık ve Yoksulluk sınırı. Erişim adresi: http:// www.turkis.org.tr/dosya/pBDme2chn8Tg.pdf. Erişim tarihi 27 Mart 2017

5. WBTi Evaluation Report-2020 Launched Webinar's Video-Recording on Launch of WBTi Evaluation Report 2020. Available at: https://www. worldbreastfeedingtrends.org/article/wbti-evaluationreport-2020-launched. Accessed June 12, 2020

6. Lande B, Andersen LF, Baerug A, et al. Infant feeding practices and associated factors in the first six months of life: The Norwegian infant nutrition survey. Acta Paediatr 2007;92:152-161. https://doi. org/10.1111/j.1651-2227.2003.tb00519.x

7. Aydın A. Anne eğitim düzeyi ve bebek dostu hastane uygulamasının altı ay tek başına anne sütü kullanımı üzerine etkileri. Ege Pediatri Bülteni 2009;16:71-78.

8. Ünsal $H$, Atlihan $F$, Özkan $H$, Targan Ş, Hassoy $H$. Toplumda anne sütü verme eǧilimi ve buna etki eden faktörler. Çocuk Sağlığı ve Hast Derg 2005;48:226233.

9. Fewtrell M, Bronsky J, Campoy C, et al. Complementary feeding: a position paper by the European Society for Paediatric Gastroenterology, Hepatology, and Nutrition (ESPGHAN) Committee on Nutrition. J Pediatr Gastroenterol Nutr 2017;64:119-132. https://doi. org/10.1097/MPG.0000000000001454

10. WHO | Complementary feeding of young children in developing countries. WHO 2014. Available at: http:// www.who.int/nutrition/publications/infantfeeding/ WHO_NUT_98.1/en. Accessed May 28, 2017

11. American Academy of Pediatrics, Kleinman RE, Greer FR. Pediatric nutrition: Policy of the American Academy of Pediatrics. Available at: https://ebooks. aappublications.org/content/pediatric-nutrition-8th-ed. Accessed Jun 11, 2017

12. Bolling K, Grant C, Hamlyn B, Thornton A. Infant feeding survey 2005. Available at: http://data.parliament.uk/ DepositedPapers/Files/DEP2008-0853/DEP20080853.pdf. Accessed September 06, 2016
13. Koletzko B, Dokoupil K, Reitmayr S, Weimert Harendza B, Keller E. Dietary fat intakes in infants and primary school children in Germany. Am J Clin Nutr 2000;72:1392-1400. https://doi.org/10.1093/ ajen/72.5.1392s

14. Köksal E, Yalçın SS, Pekcan G, Özbaş S, Tezel B, Köse MR. Complementary feeding practices of children aged 12-23 months in Turkey. Cent Eur J Public Health 2015;23:149-154. https://doi.org/10.21101/cejph. a3988

15. Ünalan PC, Akgün T, Çiftçili S, Boler İ, Akman M. Bebek dostu bir ana çocuk sağlığı merkezinden hizmet alan anneler neden bebeklerine erken ek gıda vermeye başlıyor? Türk Ped Arş 2008;43:59-64.

16. Karkee R, Lee AH, Khanal V, Binns CW. Infant feeding information, attitudes and practic: A longitudinal survey in central Nepal. Int Breastfeed J 2014;9:1-5. https:// doi.org/10.1186/1746-4358-9-14

17. Schiess S, Grote V, Scaglioni S, et al. Introduction of complementary feeding in 5 European countries. J Pediatr Gastroenterol Nutr 2010;50:92-98. https://doi. org/10.1097/MPG.0b013e31819f1ddc

18. Battaloğlu İnanç B. 15-49 yaş arası annelerin anne sütü ile ilgili uygulamaları ve etki eden faktörleri. Türkiye Aile Hek Derg 2013;1:51-55. https://doi.org/10.2399/ tahd.13.63835

19. Kaya Z, Yiğit Ö, Erol M, Gayret ÖB. Altı-yirmi dört ay arası yaş grubunda beslenmeyle ilgili anne ve babaların bilgi ve deneyimlerinin değerlendirilmesi. Med Bull Haseki 2016;54:70-75. https://doi.org/10.4274/ haseki.2756

"Çalışmamız 2. Avrasya Sosyal Pediatri Kongresi'nde (2020) sözlü sunum olarak kabul edilmiştir".

Etik kurul onayı: Ege Üniversitesi Tıp Fakültesi Girişimsel Olmayan Klinik Araştırmalar Etik Kurulu tarafından onaylandı (tarih: 18.04.2017 ve no: $17-4.1 / 15)$.

\section{Yazarların makaleye olan katkıları}

F.K. çalışmanın ana fikrini ve hipotezini kurgulamışlardır. F.K. ve G.Ş. teoriyi geliştirmiş, gereç ve yöntem bölümünü düzenlemişlerdir. Sonuçlar kısmındaki verilerin değerlendirmesini F.K., Ş.G., ve G.Ş. yapmışlardır. Makalenin tartışma bölümü F.K., Ş.G. ve G.Ş. tarafından yazılmış, F.K. gözden geçirip gerekli düzeltmeleri yapmış ve onaylamıştır. Ayrıca tüm yazarlar çalışmanın tamamını tartışmış ve son halini onaylamıştır. 